\title{
Zika Virus: A New Chapter in the History of Medicine
}

\author{
Vírus Zika: Um Novo Capítulo na História da Medicina
}

Carlos BRITO $\square^{1}$

Acta Med Port 2015 Nov-Dec;28(6):679-680

Keywords: Aedes; Arboviruses; Flavivirus; Flaviviridae Infections.

Palavras-chave: Aedes; Arbovirus; Flavivírus; Infecções por Flaviviridae.

\section{A change in the clinical-epidemiological pattern}

Zika virus is an arbovirus of the Flaviviridae Family. Its identification occurred in 1947 in Uganda; however, the occurrences of human infection were reported in an isolated and sporadic form with a large part of asymptomatic individuals.

The epidemic potential was perceived since 2007 in Micronesia; however, in 2013, mainly in the French Polynesia, a change in the pattern was observed, with high rates of attack, estimating the occurrence in $11 \%$ of the population. ${ }^{1}$

In Brazil, since November 2014 and mainly in the beginning of 2015 , the Northeast states reported a great outbreak of a new exanthematic disease. The clinical condition, characterized by an early onset exanthema, with no or little fever, accompanied by arthralgia, articular edema and conjunctivitis, led the infectologist Kleber Luz to consider the hypothesis of Zika virus. This was confirmed in April 2015 through PCR performed on eight of the 25 blood samples from suspected cases in Bahia, and subsequently in eight of the 21 cases in Rio Grande do Norte. ${ }^{2,3}$

The outbreak presented a high rate of attack, with thousands people affected overcrowding the public and private emergency services, although it was not measured by an official notification system. Since this was not a disease of mandatory notification, even in cases suspected of Zika, doctors of the services were oriented by the health inspection surveillance to notify as Dengue.

After the outbreak of the disease in its classical form, neurological and microcephaly cases began to arise.

\section{The complications: neurological cases}

The onset of neurological cases potentially associated with Zika was initially described in the French Polynesia in 2013, where, after the epidemic of Zika, seventy-two cases of patients with neurological symptoms were reported, 40 of them with Guillain-Barré syndrome. The association was suggested on the basis of clinical and epidemiology features, however without any virus isolation ${ }^{1}$.

After the outbreaks of Zika, an increase of neurological cases was noticed in the Northeast of Brazil since April 2015. In the state of Pernambuco, seven patients presented positive results for Zika by PCR-TR and viral isolation, of which six in serum samples and one in liquor. In these cases, four were diagnosed with Guillain-Barré syndrome, two with acute disseminated encephalomyelitis (ADEM) and one with meningoencephalitis. Seventy other cases are under investigation aiming the detailing of this outbreak. ${ }^{4}$

The demonstration of the first confirmed cases of Zika with neurological disorders, alerts to a potential and serious public health problem which can reach countries with the circulation of Zika virus. In Brazil, the outbreaks of Zika were limited to the Northeast, but as the transmitter mosquito is present in the whole country, the epidemic tends to reach other highly populated states, with a potential risk of neurological figures associated to an important morbidity and mortality rate.

\section{Microcephaly: the investigation of an outbreak}

On October 19, 2015, I was called by physicians of Pernambuco to evaluate an atypical situation characterized by a large increase of microcephaly cases. There were 58 cases in a single month from different cities, a much higher number than the total number of cases registered in previous years by the National System of Live Births, with five cases in 2011, nine in 2012, 10 in 2013 and 12 in 2014, an average rate of 0.5 per 10000 live births. After this initial alert, other Northeast States began to realize the increase of cases of microcephaly.

Primary (genetic) and secondary causes were suggested, but the initial investigation of these cases rose the hypothesis that this increase of microcephaly could be associated to Zika $V$ infection, based on the following clinical-epidemiological aspects and in the differential diagnosis:

- The outbreak of many cases in a short space of time, occurring simultaneously in different Cities and States, characterizes a disease with high attack rates and rapid dispersion, a phenomenon associated with disease transmitted by arthropods;

\footnotetext{
1. Professor Adjunto. Universidade Federal de Pernambuco. Recife. Brasil.

$\triangle$ Autor correspondente: Carlos Brito. cbritoc@gmail.com

Recebido: 28 de Dezembro de 2015 - Aceite: 28 de Dezembro de 2015 | Copyright @ Ordem dos Médicos 2015
} 
- Besides the microcephaly, image exams presented some common characteristics such as: periventricular and cortical microcalcifications, vernix cerebellar hypoplasia and in some cases lisencephaly compatible with the pattern of congenital infections;

- Diseases associated to TORCH (toxoplasmosis, rubella, cytomegalovirus, syphilis, HIV, parvovirus $\mathrm{B} 19$, etc) because of the transmission pattern, are not associated with large outbreaks;

- The investigation in prenatal and perinatal were negative for TORCH infections;

- Most of the mothers (70\%) reported compatible features of Zika disease in the first trimester of pregnancy, the period in which the Zika $\mathrm{V}$ outbreak occurred in the region;

- Zika has a greater neurotropism than other arboviruses;

- Other arboviruses such as dengue, endemic and epidemic in the region, are not associated to congenital malformations; or chikungunya that although being associated with perinatal disease, there is no evidence of malformations. Also Chik $\mathrm{V}$ has not been detected in many States in the Northeast regions in the beginning of the year yet.

The growing number of cases and the available evidence made the Health Ministry of Brazil declaring a state of health emergency about 25 days after the initiation of the investigation. ${ }^{5}$

On November $17^{\text {th }}$, a specialist in fetal medicine from another State (Adriana Melo), identified in amniotic fluid by RT-PCR the Zika V infection in a pregnant woman on her fifth month of pregnancy, whose baby presented microcephaly. On November $28^{\text {th }}$, virologist Pedro Vasconcelos detected the presence of the virus in the blood tests and tissues of two stillbirths with microcephaly, reinforcing and confirming the association of congenital malformation to Zika virus.

After the Brazilian alert, the French Polynesia recognized

\section{REFERENCES}

1. Ioos S, Mallet H-P, Goffart IL, Gauthier V, Cardoso T, Herida M. Current Zika virus epidemiology and recent epidemics. Med Mal Infect. 2014;44:302-7.

2. Zanluca C, Melo VC, Mosimann AL, Santos GI, Santos CN, Luz K. First report of autochthonous transmission of Zika virus in Brazil. Mem Inst Oswaldo Cruz. 2015;110:569-72.

3. Campos GS, Bandeira AC, Sardi SI. Zika virus outbreak, Bahia, Brazil. Emerg Infect Dis. 2015;21:1885-6.

4. PAHO/WHO. Epidemiological Alert. Neurological syndrome, congenital
17 cases of microcephaly in that region after the outbreak of Zika, the previous average number of cases was $0-2$ cases of microcephaly per year.

The epidemiological Bulletin of the Health Ministry of Brazil in December 2015, reported until that date, 2165 cases of microcephaly under investigation throughout the country.

Other anomalies besides microcephaly started being identified, such as osteomuscular malformations, visual and auditory alterations. These may be related to the moment in which the infection occurred, which reinforces the need to extend the investigation and characterize a new 'syndrome associated to congenital infection by Zika' or simply 'congenital Zika', as it happens with other congenital infections that present defined patterns.

The demonstration that Zika virus can lead to microcephaly brings new concepts and risks related to congenital infections, which did not exist until now. This is possible due to the etiologic agent of these congenital malformations being transmitted by the mosquitoes, a vector without prospect of elimination at medium and short term in most of the countries where Aedes circulates. This will lead to insecurity for women in the fertile period, who wish to become pregnant and eventually will lead to changes even in the family planning guidance and individual prevention measurements (the use of mosquito repellent, appropriate clothing, screens at home).

\section{The future}

The short-term actions must be directed to combating the vector and aiming to reduce the vector density. At medium and long term, work should be done to develop antiviral therapies in face of the occurrence of exposure in pregnant women, with particular efforts being directed towards the development of a vaccine.

malformations, and Zika virus infection. Implications for public health in the Americas 1 December 2015. [Consulted 2015 Dez 28]. Available from: http://reliefweb.int/sites/reliefweb.int/files/resources/2015-dec-1cha-epi-alert-zika-neuro-syndrome\%2520\%282\%29.pdf.

5. Protocolo de vigilância e resposta à microcefalia relacionada à infecção pelo vírus Zika. [Consulted 2015 Dez 26]. Available from: http:// portalsaude.saude.gov.br/images/pdf/2015/dezembro/09/Microcefalia--Protocolo-de-vigil--ncia-e-resposta---vers--o-1----09dez2015-8h.pdf. 


\section{Zika Virus: A New Chapter in the History of Medicine}

Acta Med Port 2015:28:679-680

Publicado pela Acta Médica Portuguesa, a Revista Científica da Ordem dos Médicos

Av. Almirante Gago Coutinho, 151

1749-084 Lisboa, Portugal.

Tel: +351218428215

E-mail: submissao@actamedicaportuguesa.com

www.actamedicaportuguesa.com

ISSN:0870-399X | e-ISSN: 1646-0758

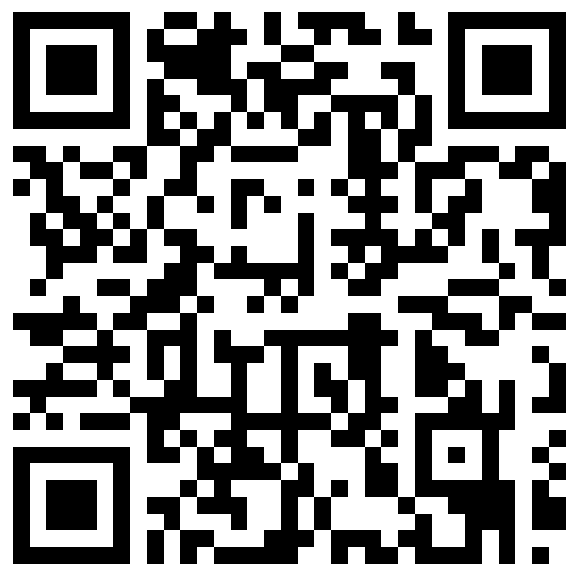

